\title{
Sociocultural preconditions for institutionalization of "city management" into the system of Russian municipal government
}

\author{
Alexander Dyatlov ${ }^{1 *}$, Vitaly Kovalev ${ }^{1}$, Victor Chygryn ${ }^{2}$ \\ ${ }^{1}$ Southern Federal University, Russia, 344000 Rostov-on-Don, Russian Federation \\ ${ }^{2}$ Crimean Federal University, Russia, 344000 Rostov-on-Don, Russian Federation
}

\begin{abstract}
This article attempts to make an analysis of sociocultural preconditions for the introduction of a mechanism for electing the head of municipal education on the basis of the competitive selection procedure. The results of a mass sociological survey on mental programs and modal models of social behavior in the South of Russia were used as empirical data. As a result of the study, the authors concluded that the order of competitive selection for the appointment of the head of municipal education is determined by the sociocultural values underlying the modern Russian Mentality.
\end{abstract}

\section{Introduction}

In a sense, the topic of our article can be qualified as a private issue of the formation of a model of municipal power in the Russian Federation. Indeed, after the elimination of the Soviet organization of power on the ground in 1991, the modern Russian government is in constant search of better principles and structural interactions in the system of local government. These searches are reflected in the state of local government legislation, which is subject to either global or private restructuring, which takes place almost every year. Of course, this demonstrates the intention of the ruling power elites to solve a number of problems simultaneously, which may well require a consistent staging and a phased solution, as a number of them are on mutually exclusive paradigmatal Grounds. Such problems include the democratization of the management process (a requirement rooted in the late 1980s), the achievement of governance efficiency (primarily in terms of improving performance socio-economic development of the territories), creating conditions for social stability (this syncretic term refers to the sustainability of the main social institutions, which have reached a certain level at which power is capable of provide a favourable and socially acceptable environment for the livelihood of the main population groups).

The history of permanent transformations has shown that an attempt to approach these problems in a comprehensive manner at this stage is untenable. It faces both objective difficulties and subjective misunderstanding sway on the part of territorial communities of the value and semantic occupancy of the proposed reforms. Thus, the declared values of

\footnotetext{
${ }^{*}$ Corresponding author: avdyatlov@yandex.ru
} 
freedom of municipal government, enshrined in the 1993 Russian Constitution, have become in many ways alien to the Russian population. Municipal elections to the authorities were not very popular, and grassroots forms of local democracy (citizens' gatherings, legal initiative, public hearings, conferences, toss, etc.) still do not cause the expected initiative to which the expected initiative, to which, is not the drafters of the Federal Law on the General Principles of Local Government Organization in the Russian Federation were calculated. As a result, the concept of municipal government as the most important structural link in the system of horizontal relations of civil society, which was to be built and structured on the basis of personal initiative of citizens, in the practice of real execution failed.

In our article, we set a goal to analyze the sociocultural prerequisites for the approval and development of the "city management" model in the system of Russian municipal government.

\section{Results and discussion}

Article was carried out within the framework of the implementation of the RFFI grant, Project No. 18-011-01113 "Institute of City Management in Modern Russia: Administrative and Public Integrity (on the example of municipal entities of the Southern Federal District)."

For mally, the model of city management can hardly be considered democratic. There is a departure from the principle of direct democracy, the embodiment of which has long been considered the normative order of the formation and implementation of local authorities. However, here we do not set the task of solving the problem either in terms of political aspects or even on the legal side of the issue. We are interested in sociocultural grounds for implementation administrative and political management practices. This translates the problem into a slightly different plane: to define the willingness of the population to recognize the mechanism of city management as a principle consistent with its ideas about the interaction between society and the authorities, on the one hand, and at different levels power among themselves, on the other hand. In other words, it is necessary to understand whether democracy, the organic part of which should be considered a model of direct elections, is included in the system of basic principles of the Russian mentality.

We will respond to the results of a mass sociological survey on the topic "Mental programs and modal models of social behavior in the South of Russia" conducted by the method of personal questionnaire in June-August 2017 in six subjects of the Russian Federation on the South of Russia (sample total - 3900 respondents). The sample included such regions as The Rostov region, the republic of Kabardino-Balkariya, the Republic of Adygea, the Republic of Crimea, the Stavropol region and the Krasnodar region. This poll captures the gradual erosion of democratic values in the minds of the Russian society. Thus, the authors drew attention to a fairly small number of respondents who chose the answer about the desirability of such a social and political system, where democracy and the provision of rights and freedoms would be its main grounds. In the South of Russia, only $24 \%$ chose this social and political system. At the same time, one in three respondents chose two options as necessary: "strong state power" and "independence from the West in politics". The latter is particularly noteworthy, which is more valuable to respondents than "democracy" and "rights and freedoms". It is also important to note that about $40 \%$ were in favour of stability and order, which significantly exceeds the frequency of choice of values traditionally associated with democratic values.

Such a distribution of responses formulated in order to identify the importance of democratic political values may indicate their insignificance in the hierarchy of values of the people of the South of Russia. This is confirmed by the clarification of this conclusion 
through a number of other issues containing other democratic positions, which are invariably part of the structure of democratic principles that construct and typical of the political regime. mechanisms of interaction between the state and society. For example, the most commonly chosen democratic value was "freedom of speech" - 18.6\%. This, of course, is itself a very low figure. However, the most insignificant was not even this option of response, but the "right to choose representatives of the authorities", the importance of which was stated by only $8.6 \%$ of respondents. For our problem, this figure is particularly relevant, as we consider, so far only potentially, the willingness on the part of territorial communities to protest as a response to the deprivation of his right to choose the head of the municipal education.

To better understand the importance of municipal elections for territorial communities, the following nuance stowed. In Russia, both in the South of the country and within the population of the entire Federation, there is one curious dissonance: the minimum of confidence in elected bodies (parties - 5.5\%, state Duma - $8 \%$, municipal government $4.5 \%$ ) and the maximum of confidence in the President of the country, which on average can be determined at $75 \%$ (Table 1 ).

Table 1. Sociocultural values of the Russian population [7]

\begin{tabular}{|l|c|c|}
\hline Elements & \multirow{2}{*}{ RF, \% } & \multirow{2}{*}{$\begin{array}{c}\text { South of } \\
\text { Russia, \% }\end{array}$} \\
\cline { 1 - 2 } Conservative sociocultural elements & & \\
\hline Public property as the basis of the country's economic well-being & 16,0 & 21,6 \\
\hline State ownership of land & 25,0 & 26,7 \\
\hline Approval of the current government & 40,0 & 38,6 \\
\hline Independence from the West in politics and economics & 37,0 & 27,1 \\
\hline Social justice & 36,0 & 37,8 \\
\hline The desire to "be like everyone else" & 45 & 42,9 \\
\hline Stability and order in society & 63,0 & 38,8 \\
\hline Social support for the state & 55,0 & 52,7 \\
\hline Ready to be an employee and receive a stable salary & 48,0 & 37,0 \\
\hline Liberal socioculture & \multicolumn{2}{|}{} \\
\hline Freedom of economic activity & 26,0 & 21,4 \\
\hline Democracy, ensuring the rights and freedoms of citizens & 13,0 & 24,2 \\
\hline Privacy and protection of private property & 26,0 & 27,9 \\
\hline Priority respect for individual rights & 19,0 & 19,5 \\
\hline Income inequality as the norm of the market economy & 9,0 & 7,3 \\
\hline Conditions for free movement and change of residence & 10,0 & 16,1 \\
\hline Ready to participate in social and political life & 13,0 & 6,1 \\
\hline Ready to participate in protest rallies & 6,0 & 11,7 \\
\hline
\end{tabular}

It is no coincidence that the population of municipalities showed extremely low electoral activity, as it connected the solution of local problems not with the activities of municipal authorities, and not even with regional structures, but with federal President.

These political preferences are reflected in the general sociocultural attitudes of Russian citizens, which we will present in a table form. 
Here, in the table data, two dichotomic scales of values, fixing conservative and liberal patterns of behavior, are defined. It should be noted, and this is clearly an absolute fact, conservative values were more popular among respondents of both the South of Russia and the entire Russian Federation. At the same time, we can talk about the rooting and some of the liberal and economic values. Thus, Russians equally recognize the value of both public and private property. However, liberal-political values were much less likely to come to the attention of respondents than conservative-political values. For example, the conservative idea of social justice among all respondents of the South of Russia was supported by $37.8 \%$, and the willingness to participate in social and political life, which corresponds to behavior within the liberal model, only $6.1 \%$. Similar significant gaps in preferences are formed in other positions.

Such a small number of respondents who have chosen liberal values reflects the characteristic feature of the present, its symptoms, manifested in the erosion of public confidence that the democratic transit that started at the beginning The 1990s are now able to lead Russia to the standards and norms of life that have developed in the West during its entire period of development.

At the same time, it should be understood that the consciousness of the modern Russian has an eclectic, in a sense - antinomic, character. Therefore, too categorical division between conservatives and liberals to a certain extent can be considered conditional, because in reality there is a interweaving of values of a diverse nature. In this regard, we are ready to recognize the four-dimensional classification of the sociocultural values of the modern russian population, which includes liberal, conservative, liberal-state and stateliberal, not double, justified. patterns of behavior (Table 2).

Table 2. Comparative analysis of models of sociocultural behavior in Russia as a whole and in the South of Russia

\begin{tabular}{|l|c|c|}
\hline Models of sociocultural behavior & RF, in \% & $\begin{array}{l}\text { South of } \\
\text { Russia, \% }\end{array}$ \\
\hline Liberal model & 4 & 10 \\
\hline Conservative model & 20 & 25 \\
\hline Liberal-state model & 14 & 15 \\
\hline State-liberal model & 62 & 50 \\
\hline
\end{tabular}

The state-liberal model assumes recognition as significant of certain market principles (private property, protection of rights and freedoms), but defending them by methods typical of traditional Russian conservatism: maintenance stability, a strong state, an emphasis on justice, etc.

\section{Conclusions}

Analysis of sociocultural behaviors, most typical for The Russian society, including in the South of Russia, gives the right to assume that municipal democracy is not perceived by the Russian society as something meaningful for itself. In general, one can be sure that the population of municipalities will not actively protest and express in some other way their regrets about the cancellation of the procedure of direct elections for the post of head of municipal education. Especially if the authorities manage to find sufficient financial resources for the socio-economic development of the territories.

In the conclusion of our study, we can note that the implementation of the procedure of competitive appointment of the head of municipal education is determined by sociocultural grounds. The introduction of the city-management mechanism was possible because the 
concept of a strong state implementing paternalistic functions is inherent in the Russian political consciousness. There is reason to believe that the vast majority of the population of municipalities, suspended from the procedure of elections of the head of the local government, will not only not participate in public protests against the "squeezing" convenient for the authorities competitive procedure, but, on the contrary, will accept the new mechanism as the most acceptable for itself.

This article was completed as part of the implementation of the RFBR grant, project No. 18-01101113, "The Institute of City Management in Modern Russia: Administrative and Social Solvency (using the example of municipalities of the Southern Federal District)."

\section{References}

1. Federal law of October 6, 2003 No.131-Fz "On the general principles of local government organization in the Russian Federation" (2003)

2. I.V. Vydrin. Herald of the Ural Institute of Economics, Management and Law. 2, (2011)

3. V.I. Vasilyev. Journal of Russian law. 4, (2012)

4. Mental programs and modal models of social behavior in the South of Russia: monograph (Social and humanitarian knowledge, Moscow, 2017)

5. V.S. Avdonin. Pro Nunc. Modern political processes. 1, (2015)

6. Yu.G. Volkov, A.V. Lubsky, V.P. Voytenko, Yu.S. Panfilova. Journal of Engineering and Applied Sciences. 12, (2017)

7. A.V. Lubsky, E.Y. Kolesnykova, R.A. Lubsky. International Journal of Environmental and Science Education. 11 (16), (2016)

8. Yu.G. Volkov, K.V. Vodenko, A.V. Lubsky, A.K. Degtyarev, I.P. Chernobrovkin. Information. 20 (7), (2017)

9. A.V. Bedrik, I.P. Chernobrovkin, A.V. Lubskiy, Y.G. Volkov, N.A. Vyalykh. Indian Journal of Science and Technology. 9 (5), (2016) 